\title{
STATUS PEKERJAAN PADA PETERNAKAN SAPI PERAH DAN KAITANNYA DENGAN TINGKAT KESEJAHTERAAN
}

\author{
Status of Work on Farms Dairy Cattle and with Respect to the Level of Welfare
}

Eva Masrivah Febriani*) dan Saharuddin

Departemen Sains Komunikasi dan Pengembangan Masyarakat, Fakultas Ekologis Manusia, IPB

\begin{abstract}
Livelihoods some residents in the village of Situ Udik is derived from the farm, it is supported by the regional development of the farm or Kunak KPS Bogor. On this farm there are various areas of work status and various livelihood strategies that households choose to make ends meet. Employment status as well as the strategy chosen households living on a dairy farm could be something to do with the availability livelihood of farmers in the form of assets of natural capital, physical capital, human capital, financial capital and social capital. Various status of that work will certainly affect the standard of living or level of household welfare. Therefore, this study aimed to analyze the effect on the employment status of household welfare in dairy cattle breeding business district KPS Bogor. The study was conducted using quantitative methods supported by qualitative methods. The results showed that employment status affects household welfare level and the level of household welfare in dairy cattle is relatively high.
\end{abstract}

Keywords: livehood assets, livelihood strategies, status of employment, the level of welfare of households.

\section{ABSTRAK}

Sumber nafkah sebagian warga di Desa Situ Udik adalah berasal dari peternakan, hal tersebut didukung oleh adanya pengembangan kawasan usaha peternakan atau KUNAK KPS Bogor. Pada kawasan peternakan ini terdapat beragam status pekerjaan serta berbagai strategi nafkah yang rumah tangga pilih untuk memenuhi kebutuhan hidup. Status pekerjaan serta strategi nafkah yang dipilih rumah tangga pada peternakan sapi perah ini bisa jadi ada hubungannya dengan ketersediaannya livelihood asset peternak yang berupa modal alam, modal fisik, modal manusia, modal finansial dan modal sosial. Berbagai status pekerjaan itu pula tentunya akan mempengaruhi taraf hidup atau tingkat kesejahteraan rumah tangganya. Oleh karena itu, penelitian ini bertujuan untuk menganalisis pengaruh status pekerjaan terhadap tingkat kesejahteraan rumah tangga pada peternakan sapi perah kawasan usaha peternakan KPS Bogor. Penelitian dilakukan dengan menggunakan metode kuantitatif didukung dengan metode kualitatif. Hasil penelitian menunjukkan bahwa status pekerjaan mempengaruhi tingkat kesejahteraan rumah tangga dan tingkat kesejahteraan rumah tangga pada peternakan sapi perah ini tergolong tinggi.

Kata kunci : livelihood asset, rumah tangga, status pekerjaan, strategi nafkah, tingkat kesejahteraan.

\section{PENDAHULUAN}

\section{Latar Belakang}

Peternakan sapi perah merupakan salah satu sub sektor pertanian yang berpotensi untuk dikembangkan. Menurut Ditjen Peternakan (2011), peternakan sapi perah di Indonesia belum berkembang baik, tergambar dari produksi nasional yang baru mencapai 25-30 persen dari kebutuhan susu nasional, sehingga sisanya dipenuhi dari impor negara lain (Australia, New Zealand) dalam bentuk susu dan produk olahannya. Dari sisi konsumsi, masyarakat Indonesia mengkonsumsi sekitar 11,1 liter/kapita/tahun, masih rendah dibanding dengan negara lainnya. Konsumsi susu penduduk Malaysia, Singapura dan Thailand rata-rata 30 liter/kapita/tahun serta Vietnam sekitar 12 liter/kapita/ tahun.

Meningkatnya pendapatan masyarakat dan meningkatnya jumlah penduduk Indonesia, maka kemungkinan besar konsumsi produk-produk susu akan meningkat. Adanya ketimpangan antara produksi susu sapi (909.532 ton) yang dihasilkan dengan permintaan (3.864.454 ton) merupakan potensi untuk pengembangan usaha peternakan sapi perah dengan menunjang peningkatan produksi susu dalam negeri.

Pengembangan usaha peternakan sapi perah memiliki prospek yang besar dalam mendorong terwujudnya program swasembada susu tahun 2020. Populasi sapi perah saat ini di Indonesia berdasarkan hasil sensus BPS tahun 2011, sebesar 496.000 ekor persentase sebesar $80 \%$ ada di Pulau Jawa dengan produksi susu segarnya 1800 ton per atau setara dengan nilai 6 milyar rupiah. Untuk bisa mencapai swasembada susu tahun 2020, maka populasi sapi perah haruslah mencapai 2,3 juta ekor pada tahun 2020. Komitmen politik untuk mendukung penganggaran dalam mencapai populasi tersebut diperlukan untuk memperbanyak jumlah peternak dan jumlah populasi sapi saat ini. 
Jumlah peternak sapi perah saat ini sekitar 100 ribu lebih dengan kepemilikan sapi berkisar 2-4 ekor per peternak, yang sebagian besar bersatu dalam wadah koperasi. Bogor merupakan salah satu wilayah yang sudah melaksanakan pengembangan usaha peternakan sapi perah, terbukti dengan adanya Koperasi Produksi Susu dan Usaha Peternakan (KPS) Bogor yang didirikan pada tanggal 21 Oktober 1970. Meskipun dalam kegiatannya mengalami banyak kendala, namun seiring dengan berjalannya waktu dan adanya bantuan dari pemerintah, pada tahun 1990-1996 KPS Bogor melakukan pengembangan Kawasan Usaha Peternakan (KUNAK) sapi perah di wilayah kecamatan Cibungbulang dan Pamijahan. Bahkan pada tahun 1994 KPS Bogor pernah meraih beberapa prestasi diantaranya koperasi terbaik tingkat Kabupaten maupun propinsi yaitu sebagai Koperasi produsen terbaik II. Pada tanggal 25 Maret 1996 nama Koperasi Produksi Susu dan Peternak Sapi perah diubah menjadi Koperasi Produksi Susu dan Usaha Peternakan (Ridwan, 2011).

Desa Situ Udik merupakan desa dari Kecamatan Cibungbulang yang merupakan wilayah pengembangan Kawasan Usaha Peternakan (KUNAK) KPS Bogor, meskipun koperasi KUNAK terdapat di Desa Pamijahan namun ada tiga kelompok peternak sapi perah yang merupakan anggota dari koperasi KUNAK tersebut berada di Desa Situ Udik. Jumlah rumah tangga peternak sapi perahnya pun lebih banyak jika dibandingkan dengan desa yang lain. Banyak hal yang perlu diperhatikan untuk mendorong pengembangan usaha peternakan sapi perah, salah satu diantaranya adalah mempertimbangkan karakteristik dan kondisi geografis, ekologi, serta kesuburan lahan. Selain itu, adapun yang paling penting untuk diperhatikan adalah kualitas sumberdaya manusianya, dalam hal ini adalah para peternak sapi perah. Dalam usaha peternakan sapi perah, para peternak sapi perah biasanya tergabung dalam kelompok yang diwadahi oleh sebuah koperasi. Tujuannya agar peternak sapi perah yang tergabung dalam kelompok peternak sapi perah tersebut mampu bekerja sama satu sama lain, dan menjadi kelompok yang dinamis serta berkembang. Seperti yang dijelaskan oleh Santosa (2004) bahwa individu sebagai makhluk hidup mempunyai kebutuhan yang menurut A. Maslow dikenal sebagai: kebutuhan fisik, kebutuhan rasa aman, kebutuhan kasih sayang, kebutuhan prestasi dan prestise, serta kebutuhan untuk melaksanakan sendiri. Di lain pihak, individu memiliki potensi untuk memenuhi kebutuhan tersebut, namun potensi yang ada pada individu yang bersangkutan terbatas sehingga individu harus meminta bantuan kepada individu lain yang sama-sama hidup satu kelompok.

Pemenuhan kebutuhan hidup tersebut mengharuskan rumah tangga peternak sapi perah melakukan strategi nafkah agar mereka dapat bertahan hidup dan bisa mencukupi kebutuhan hidup rumah tangganya, baik itu kebutuhan dasar maupun kebutuhan penunjang lainnya. Strategi nafkah setiap rumah tangga peternak sapi perah tentunya akan beragam, hal itu didasarkan pada kondisi karakteristik peternak sapi perah dan sumber daya yang ada, serta faktor lain yang mampu mempengaruhi keputusan peternak dalam menentukan strategi nafkahnya.

Banyaknya resiko yang dihadapi oleh rumah tangga peternak sapi perah seperti susahnya mencari pakan pada musim tertentu, semakin bertambah mahalnya harga konsentrat, dan adanya sapi perah yang sakit bahkan bisa sampai mati serta resiko-resiko lainnya juga merupakan salah satu dari berbagai alasan rumah tangga peternak sapi perah melakukan strategi nafkah. Meskipun rumah tangga peternak sapi perah ini berada di Kawasan Usaha Peternakan dan menjalin kerjasama dengan koperasi serta membentuk kelompok, namun hal tersebut tidak sepenuhnya dapat dijadikan jaminan bahwa semua peternak sapi perah yang berada di kawasan tersebut hidup sejahtera atau sudah mampu memenuhi kebutuhan hidup yang lebih layak. Berdasarkan Undang-Undang Republik Indonesia No 11 Tahun 2009 pasal 1 ayat 1 menyebutkan bahwa Kesejahteraan Sosial adalah kondisi terpenuhinya kebutuhan material, spiritual, dan sosial warga negara agar dapat hidup layak dan mampu mengembangkan diri, sehingga dapat melaksanakan fungsi sosialnya.

Mengingat bahwa tidak semua rumah tangga peternak sapi perah yang ada di kawasan tersebut memiliki status pemilik sapi perah/ternak pribadi, karena ada beberapa peternak yang memperternakan sapi perah dari investor atau kombinasi dari keduanya. Oleh karena itu, menjadi menarik untuk meneliti lebih lanjut tentang status pekerjaan pada peternakan sapi perah beserta strategi nafkah rumah tangga peternak sapi perah yang berada di wilayah pengembangan Kawasan Usaha Peternakan (KUNAK) KPS Bogor, serta dampaknya terhadap kehidupan rumah tangga peternak sapi perah tersebut.

Hal ini menarik untuk diteliti, karena bagaimanapun rumah tangga peternak sapi perah ini adalah faktor terbesar yang menentukan apakah program swasembada susu tahun 2020 akan tercapai atau tidak, sehingga pemerintah tidak perlu lagi melakukan impor susu dari negara lain dan kebutuhan gizi masyarakat pun dapat terpenuhi dengan baik, mengingat susu merupakan salah satu komoditas yang diminati oleh semua lapisan umur, baik itu balita, anak, remaja, orangtua, maupun lansia.

\section{Perumusan Masalah}

Desa Situ Udik, Kecamatan Cibungbulang, Kabupaten Bogor merupakan wilayah yang cukup baik untuk mengembangkan peternakan sapi perah, dengan adanya lahan yang masih luas, udara yang masih segar serta potensipotensi lain yang mendukung keberlanjutan peternakan, maka akan sangat mungkin usaha peternakan ini untuk berkembang. Namun tidak cukup hanya dengan potensi sumberdayanya saja yang baik, kualitas sapi perahnya pun harus unggul agar hasil produksinya berkualitas. Adapun yang lebih penting lagi adalah kualitas sumberdaya manusia yang mengelolanya, dalam hal ini tentunya peternak sapi perah. Seperti yang dijelaskan oleh Saragih (2000), bahwa tantangan pengembangan peternakan semakin berat.

Langsung maupun tidak langsung, keberhasilan pembangunan peternakan akan berpengaruh pada kualitas sumberdaya manusia Indonesia. Tantangan ini akan semakin berat jika diingat bahwa sektor peternakan tidak hanya dituntut untuk meningkatkan jumlah produksi saja tetapi juga dituntut untuk menghasilkan produk yang berkualitas serta variasi yang makin beragam dan murah harganya, sehingga dapat dikonsumsi oleh masyarakat berpenghasilan rendah.Jika di masa lalu jumlah sumberdaya manusia bisa menjadi salah satu keunggulan komparatif, maka pada masa yang akan datang jumlah saja tidak memadai lagi tetapi harus juga disertai dengan kualitas yang tinggi. Bahkan pada masa yang akan datang, kualitas 
sumberdaya manusia lebih dominan berpengaruh terhadap kemajuan (atau kemunduran) bangsa dibanding kekayaan sumberdaya alam.

Dibalik tantangan pengembangan peternakan yang semakin berat dan tuntutan untuk menjadi peternak yang berkualitas, serta tanggung jawab untuk memenuhi kebutuhan rumah tangganya maka dalam hal ini peternak harus mampu membuat keputusan atau strategi nafkah yang meminimalkan resiko. Walaupun rumah tangga peternak sapi perah ini berada dalam wilayah pengembangan Kawasan Usaha Peternakan (KUNAK) KPS Bogor yang mewadahi hasil produksi mereka, namun hal tersebut tidak sepenuhnya dapat menjamin terpenuhinya kebutuhan nafkah rumah tangga peternak, terlebih lagi di KUNAK tersebut tidak semuanya adalah pemilik sapi perah. Oleh karena itu, dalam penelitian ini, menjadi menarik untuk menganalisis bagaimana status pekerjaan pada peternakan sapi perah di wilayah pengembangan Kawasan Usaha Peternakan (KUNAK) KPS Bogor, Desa Situ Udik beserta strategi nafkahnya.

Terwujud tidaknya program pemerintah mengenai swasembada susu pada tahun 2020 tidak lepas dari peranan peternak sapi perah, maka dari itu pemerintah seharusnya memperhatikan lebih nyata kehidupan atau kesejahteraan hidup rumah tangga peternak, seperti memperhatikan sudah meningkat atau belumnya taraf hidup peternak sapi perah. Merujuk pada Undang-Undang RI Nomor 6 Tahun 1967, tentang Ketentuan-Ketentuan Pokok Peternakan dan Kesehatan Hewan pada Bab II pasal 8, bahwa peternakan diselenggarakan dengan tujuan untuk mencukupi kebutuhan rakyat akan protein-hewani dan lainlain bahan, yang berasal dari ternak yang bermutu tinggi; mewujudkan terbentuknya dan berkembangannya industri dan perdagangan bahan-bahan, yang berasal dari ternak; mempertinggi penghasilan dan taraf hidup rakyat terutama rakyat petani-peternak; mencukupi kebutuhan akan tenaga pembantu bagi usaha pertanian dan pengangkutan; mempertinggi daya-guna tanah.

Tingginya penghasilan dan taraf hidup atau dapat disebut dengan tingkat kesejahteraan peternak sapi perah ini dipengaruhi oleh kualitas pengelolaan dan hasil produksi. Jika hasil produksi susu berkualitas tinggi, maka harga pembeliannya pun akan sedikit lebih tinggi dibandingkan dengan kualitas yang biasa. Begitupun jika harga pembelian produksi susu tinggi maka tingkat pendapatan akan meningkat, dan tingkat pendapatan tersebut merupakan salah satu indikator untuk melihat tingkat kesejahteraan peternak sapi perah. Meskipun dengan adanya dukungan dari Koperasi Produksi Susu dan Usaha Peternakan (KPS) Bogor sebagai wadah produksi, tidak serta merta menjamin tingkat kesejahteraan hidup rumahtangga peternak, meskipun begitu para peternak sapi perah masih mempunyai peluang untuk mengembangkan usahanya. Oleh karena itu, menarik untuk mengidentifikasi bagaimana tingkat kesejahteraan rumah tangga pada peternakan sapi perah KUNAK KPS Bogor.

Kesejahteraan hidup rumah tangga peternak sapi perah tentunya akan berkaitan dengan status pekerjaannya. Dalam penelitian ini, tingkat kesejahteraan itu sendiri ditentukan oleh beberapa indikator yaitu tingkat pendapatan, tingkat pendidikan, tingkat kesehatan, kondisi perumahan (tempat tinggal), akses terhadap pelayanan kesehatan dan tingkat partisipasi dalam kegiatan publik, maka besar kemungkinan status pekerjaan ini bisa mempengaruhi semua indikator tersebut atau tidak. Oleh karena itu, menarik untuk mengkaji bagaimana pengaruh status pekerjaan terhadap tingkat kesejahteraan rumah tangga pada peternakan sapi perah KUNAK KPS Bogor tersebut.

\section{Tujuan Penelitian}

Berdasarkan rumusan masalah penelitian, maka tujuan dari penelitian ini adalah sebagai berikut :

1. Menganalisis status pekerjaan pada peternakan sapi perah di wilayah pengembangan Kawasan Usaha Peternakan (KUNAK) KPS Bogor, Desa Situ Udik beserta strategi nafkahnya.

2. Menganalisis tingkat kesejahteraan rumah tangga pada peternakan sapi perah KUNAK KPS Bogor.

3. Menganalisis pengaruh status pekerjaan terhadap tingkat kesejahteraan rumah tangga pada peternakan sapi perah KUNAK KPS Bogor tersebut.

\section{PENDEKATAN TEORITIS}

\section{Usaha Peternakan Sapi Perah}

Sapi perah dalam Kamus Besar Bahasa Indonesia (KBBI) diartikan sebagai sapi yang khusus dipiara untuk menghasilkan susu. Serupa dengan KBBI, Siregar (1996) yang dikutip oleh Haloho et al. (2013) juga menyebutkan bahwa sapi perah adalah sapi yang diternakkan terutama sebagai penghasil susu. Menurut Sudono (1999) yang dikutip oleh Kamiludin (2009), usaha peternakan sapi perah di Indonesia diklasifikasikan berdasarkan skala usahanya, yaitu perusahaan peternakan sapi perah dan peternakan sapi perah rakyat. Berdasarkan Keputusan Menteri Pertanian Republik Indonesia No : 362/KPTS/TN. 1201511990 , usaha perternakan sapi perah rakyat adalah usaha perternakan yang memiliki total sapi perah di bawah 20 ekor dan perusahaan perternakan sapi perah adalah usaha perternakan yang memiliki lebih dari 20 ekor sapi perah. Peternakan rakyat merupakan usaha yang dilakukan oleh rakyat disamping usaha taninya sehingga sifat pemeliharaanya masih tradisional. Perusahaan perternakan merupakan peternakan yang diselenggarakan dalam suatu perusahaan komersial dengan tujuan untuk mendapatkan keuntungan sebesar-besarnya dan mempunyai izin usaha serta dalam proses produksinya telah menggunakan teknologi baru. Selain itu pada perusahaan peternakan biasanya telah menerapkan hasil penelitian terbaru atau inovasi.

\section{Status Pekerjaan dan Strategi Nafkah Rumah Tangga}

Menurut BPS (1976) dalam Suryani (2011), status pekerjaan adalah kedudukan seseorang dalam melakukan pekerjaan di suatu unit usaha/kegiatan. Dalam sosiologi nafkah, pengertian strategi nafkah lebih mengarah pada pengertian livelihood strategy (strategi penghidupan) daripada means of living strategy (strategi cara hidup). Pengertian livelihood strategy yang disamakan pengertiannya menjadi strategi nafkah (dalam bahasa Indonesia), sesungguhnya dimaknai lebih besar daripada sekedar "aktivitas mencari nafkah" belaka. Sebagai strategi membangun sistem penghidupan, maka strategi nafkah bisa didekati melalui berbagai cara atau manipulasi aksi individual maupun kolektif. Strategi nafkah bisa berarti cara bertahan hidup atau memperbaiki 
status kehidupan. Strategi nafkah adalah taktik dan aksi yang dibangun oleh individu maupun kelompok dalam rangka mempertahankan kehidupan mereka dengan tetap memperhatikan eksistensi infrastruktur sosial, struktur sosial, dan sistem nilai budaya yang berlaku (Dharmawan, 2006)

\section{Tingkat Kesejahteraan Rumah Tangga}

Menentukan tingkat kesejahteraan keluarga atau sebut saja rumah tangga bukanlah hal yang mudah, karena kesejahteraan erat kaitannya dengan pandangan dari individu masing-masing (subjektif). Namun banyak cara yang telah dilakukan oleh beberapa orang/kelompok/ lembaga/pihak-pihak lainnya, agar mampu menggambarkan tingkat kesejahteraan dalam satu pandangan yang umum, khususnya pada saat menentukan tingkat kesejahteraan suatu keluarga atau rumah tangga. kesejahteraan keluarga menurut UU No. 10 Tahun 1992, yaitu keluarga yang dibentuk berdasarkan atas perkawinan yang sah, mampu memenuhi kebutuhan spiritual dan material yang layak, bertakwa kepada Tuhan Yang Maha Esa, memiliki hubungan yang serasi, selaras, dan seimbang antaranggota dan antara keluarga dengan masyarakat dan lingkungan.

\section{Kerangka Pemikiran}

Makhluk hidup pasti akan mempertahankan kehidupannya, begitupun dengan rumah tangga peternak sapi perah. Terlepas dari banyaknya tantangan dan resiko yang dihadapi dalam mengelola usaha peternakannya, namun kenyataan bahwa kehidupan terus berlangsung membuat para peternak mencoba berbagai cara untuk memanfaatkan sumberdaya-sumberdaya yang ada di sekitarnya. Sumberdaya yang ada bisa dijadikan modal untuk memenuhi kebutuhan hidup atau nafkah rumah tangga sehari-hari. Modal tersebut bisa berupa modal manusia, yaitu kemampuan yang dimiliki oleh individu dan hampir seluruhnya dikerahkan untuk menghasilkan kinerja yang memuaskan. Ada juga modal fisik, seperti kepemilikan aset-aset. Lalu ada modal sumberdaya alam, seperti lahan, hewan dan lainnya. Kemudian ada juga modal sosial yang biasanya berupa jaringan sosial, norma dan kepercayaan. Adapun yang terakhir adalah modal finansial seperti modal usaha, investasi ataupun tabungan. Pemanfaatan modalmodal nafkah tersebut yang dapat menentukan status pekerjaan pada peternakan sapi perah Kawasan Usaha Peternakan KPS Bogor.

Status pekerjaan pada peternakan sapi perah tersebut bisa dikatakan sudah cocok karena sudah mampu membuat rumah tangga peternak sejahtera. Namun bisa jadi juga peternak sapi perah tersebut masih mencari-cari status pekerjaan yang cocok untuknya, karena masih merasa belum sejahtera. Oleh karena itu cukup memungkinkan untuk menyimpulkan bahwa status pekerjaan pada peternakan sapi perah mampu mempengaruhi tingkat kesejahteraannya. Pandangan tentang indikator kesejahteraan keluarga atau rumah tangga sendiri cukup banyak dan beragam, namun pada dasarnya mempunyai maksud yang sama seperti yang telah ditentukan oleh undang-undang.

Dalam penelitian ini dipilih beberapa indikator yang dianggap dapat menggambarkan kesejahteraan suatu rumah tangga, khususnya rumah tangga peternak sapi perah. Indikator-indikatornya tersebut adalah tingkat pendapatan, tingkat pendidikan, tingkat kesehatan, akses terhadap pelayanan kesehatan, kondisi perumahan (tempat tinggal), dan tingkat partisipasi dalam kegiatan publik.

\section{Hipotesis Penelitian}

Penyusunan hipotesis dilakukan dalam rangka memudahkan peneliti untuk menjawab permasalahan dan untuk mencapai tujuan penelitian yang telah dirumuskan. Adapun hipotesis dalam penelitian ini adalah:

1. Status pekerjaan pada peternakan sapi perah di KUNAK KPS Bogor beragam.

2. Tingkat kesejahteraan rumah tangga pada peternakan sapi perah KUNAK KPS Bogor tinggi.

3. Status pekerjaan mempengaruhi tingkat kesejahteraan rumah tangga pada peternakan sapi perah KUNAK KPS Bogor.

\section{METODE PENELITIAN}

Penelitian menggunakan pendekatan kuantitatif dan kualitatif. Penelitian kuantitatif yang akan dilakukan merupakan penelitian survei. Metode kuantitatif dilakukan melalui pengisian kuesioner. Pendekatan kuantitatif ini diharapkan dapat menjawab pengaruh status pekerjaan terhadap tingkat kesejahteraan peternak sapi perah Kawasan Usaha Peternakan (KUNAK) KPS Bogor di Desa Situ Udik Kecamatan Cibungbulang Kabupaten Bogor. Pendekatan kualitatif dilakukan dengan menggunakan teknik wawancara mendalam terhadap informan yang tahu dan mengerti tentang kondisi peternakan sapi perah di KUNAK KPS Bogor, dan kepada rumah tangga peternak sapi perah, aparat desa serta pihak-pihak lain yang dapat melengkapi data.

Penelitian ini memilih tempat kelompok peternak sapi perah di Desa Situ Udik Kecamatan Cibungbulang Kabupaten Bogor. Lokasi dipilih secara sengaja karena lokasi kelompok peternak sapi perah ini merupakan wilayah pengembangan Kawasan Usaha Peternakan (KUNAK) sapi perah Koperasi Produksi Susu dan Usaha Peternakan (KPS) Bogor, yang pada tahun 1994 pernah meraih beberapa prestasi diantaranya koperasi terbaik tingkat Kabupaten maupun propinsi yaitu sebagai Koperasi produsen terbaik II.

Penelitian ini menggunakan metode snowball sampling, yaitu dengan mengidentifikasi orang yang dianggap dapat memberi informasi untuk diwawancara, kemudian orang ini dijadikan sebagai informan untuk mengidentifikasi orang lain sebagai sampel yang dapat memberi informasi dan orang ini juga dijadikan sebagai informan untuk mengidentifikasi orang lain sebagai sampel yang dianggap dapat memberi informasi, dan seterusnya (Silalahi, 2009). Dari hasil snowball sampling tersebut didapatkan total sampel setengah dari populasi atau sebanyak 32 rumah tangga pada peternakan sapi perah.

Pengambilan data sekunder akan dilakukan pada awal bulan Maret 2014. Pengambilan data primer akan dilakukan pada bulan April 2014 sampai dengan bulan Mei 2014. Analisis data dan penulisan akan dilakukan pada bulan Mei 2014. Kegiatan penelitian meliputi peyusunan proposal penelitian, kolokium, pengambilan data lapangan, pengolahan data dan analisis data, penulisan draft skripsi, sidang skripsi, dan perbaikan laporan penelitian. Data yang 
telah dikumpulkan menggunakan kuesioner akan diolah secara kuantitatif dengan menggunakan Microsoft Excel 2007 dan SPSS for Windows versi 17. Data Kuantitatif yang diperoleh akan dianalisis dengan menggunakan tabel frekuensi, tabel tabulasi silang. Untuk mengetahui pengaruh bentuk strategi nafkah terhadap tingkat kesejahteraan dan untuk melihat hubungan yang signifikan antar variabel digunakan uji statistik parametrik melalui uji regresi linier berganda. Selain analisis data kuantitatif, dilakukan pula analisis data kualitatif sebagai pendukung data kuantitatif. Data kualitatif akan diolah melalui tiga tahap analisis data kualitatif, yaitu reduksi data, penyajian data dan penarikan kesimpulan.

\section{GAMBARAN UMUM LOKASI PENELITIAN}

Desa Situ Udik adalah salah satu desa yang berada di Kecamatan Cibungbulang Kabupaten Bogor. Tepatnya di Kecamatan Cibungbulang bagian selatan yang berbatasan langsung dengan Kecamatan Pamijahan dan Kecamatan Leuwiliang. Dengan melihat potensi yang ada, Desa Situ Udik kedepannya bila dikelola dengan baik akan menjadi desa yang berkembang baik pertanian, perikanan maupun industri kecil dan menengah. Salah satu yang menjadi produk unggulan yaitu peternakan sapi, industri kecil dan menegah.

Hal tersebut akan menjadikan Desa Situ Udik sebagai salah satu Desa Pertanian di Kecamatan Cibungbulang. Desa Situ Udik merupakan desa dengan Pola Lokasi Desa Linear, yaitu pola lokasi wilayah-wilayah yang berada di desa ini memanjang mengikuti arah jalan raya yang melewati wilayah tersebut. Masyarakat di wilayah tersebut membangun rumah dekat dan mengikuti jalur jalan desa agar aksesibilitas lebih mudah. Desa Situ Udik merupakan desa dengan tipe desa persawahan, yaitu tipe desa yang sebagian besar kehidupan penduduknya bergantung pada potensi pertanian sawah, baik yang berpengairan teknis, dan non teknis. Mata pencaharian penduduk mayoritasnya adalah petani dan buruh tani.

Desa Situ Udik terdiri 3 Dusun, 12 RW dan 43 RT dan terbagi menjadi 22 perkampungan yaitu Kp. Kunak I, Kp. Kunak II, Kp. Pasir Putih, Kp. Babakan Satu, Kp. Suka Maju, Kp. Suka Tani, Kp. Ganda Rasa, Kp. Al- Barokah, Kp. Pasir Eurih, Kp. Malang Nengah, Kp. Gunung Handeuleum dan Kp. Sindang Sari, Kp. Batu Beulah, Kp. Cigamea, Kp. Kandang Bakti, Kp. Ganda Rasa, Kp. Pasar Sabtu, Kp. Setu II, Kp. Setu III, Kp. Setu I, Kp. Taman Tugu dan Kp. Pager Jangkung. Jumlah penduduk Desa Situ Udik pada bulan Desember 2013 sebanyak 14.500 orang yang tercatat sebanyak 7.350 orang laki-laki dan 7.150 orang perempuan.

Luas penggunaan wilayah Desa Situ Udik sekitar 60\% dari luas wilayahnya digunakan untuk area persawahan dan perkebunan, maka tak heran masyarakat Desa Situ Udik berprofesi sebagai petani dan buruh tani sebanyak \pm $20 \%$ dari jumlah penduduk. Hasil pertanian yang paling banyak ialah padi, hampir di setiap wilayah memiliki area persawahan. Tidak hanya padi, produksi pertanian seperti singkong, ubi jalar, palawija dan lain-lain cukup banyak di Desa Situ Udik.

Penganut agama di Desa Situ Udik sebanyak 14.444 orang beragama Islam dan 6 orang beragama Kristen. Sarana dan prasarana umat Islam di Desa Situ Udik sangat memadai, disetiap wilayah sudah terdapat masjid dan mushola untuk menjalankan ibadah shalat dan kegiatan lainnya seperti pengajian. Tingkat ekonomi masyarakat Desa Situ Udik tidak merata di setiap wilayah atau kampung. Kp. Kunak I merupakan wilayah yang paling tinggi tingkat ekonominya dibandingkan dengan wilayah lain, hal ini dikarenakan di Kp. Kunak I terdapat salah satu peternakan sapi perah terbesar di Kabupaten Bogor, tidak hanya itu, Kp. Kunak I juga merupakan ibukota desa situ udik sehingga jalan menuju kantor Desa Situ Udik yang kondisinya baik sehingga akses transportasi untuk pertumbuhan ekonomi sangatlah mudah. Semua jalan Desa Situ Udik 100\% di betonisasi atau di aspal sehingga pengguna jalan untuk pendistribusian barang konsumsi, hasil pertanian, penjualan, dan akses transportasi sangat mudah. Jalan Desa Situ Udik yang sangat baik dikarenakan rasa kesolidaritasan masyarakat Desa Situ Udik yang tinggi dan bisa menjadi contoh bagi desa lain yang ada di Indonesia.

Sektor peternakan sapi perah di Desa Situ Udik merupakan ciri khas dari Desa Situ Udik khususnya di wilayah kp. kunak I. Penjualan susu perah menjadi prioritas utama penjualan, hal ini terjadi karena permintaan ukuran susu sapi perah lebih banyak. Untuk penjualan sapi dan susu sapi perah sudah mencakup luar kota seperti dari Jawa Tengah, Jakarta, Jawa Timur dan Sumatera. Industri Rumahan yang terdapat di Desa Situ Udik yang menjadi ciri khas ialah konveksi pakaian, budidaya jamur, peternakan kelinci, petenakan ayam, pengrajin timah, pabrik roti, pengrajin sandal, pengrajin sepatu olah raga dan pengrajin anyaman

\section{KARAKTERISTIK RESPONDEN}

\section{Umur Responden}

Pada umumnya umur peternak sapi perah di KUNAK ini berkisar antara 23 tahun sampai 52 tahun, hal ini menunjukkan bahwa sebagian besar responden berada pada usia produktif.

Tabel 1. Jumlah dan Persentase Responden Menurut Kategori Umur

\begin{tabular}{lcc}
\hline Umur (tahun) & Jumlah responden & Persentase \\
\hline $23-37$ & 15 & 47 \\
$38-52$ & 15 & 47 \\
$>52$ & 2 & 6 \\
Total & 32 & 100 \\
\hline
\end{tabular}

Jumlah Tanggungan Responden

Tabel 2. Jumlah dan Persentase Responden Menurut Jumlah Tanggungan

\begin{tabular}{lcc}
\hline $\begin{array}{l}\text { Jumlah } \\
\text { gan }\end{array}$ & $\begin{array}{c}\text { tanggun- } \\
\text { Jumlah respon- } \\
\text { den }\end{array}$ & Persentase \\
\hline $1-3$ & 19 & 59 \\
$4-6$ & 12 & 38 \\
$>6$ & 1 & 3 \\
Total & 32 & 100 \\
\hline
\end{tabular}

Sebagian besar peternak sapi perah mempunyai jumlah 
tanggungan keluarga antara 1 orang sampai 3 orang, hal ini dikarenakan masih banyaknya rumah tangga muda serta adapun karena para istri dari peternak rajin melakukan KB.

\section{Tingkat Pendidikan Responden}

Pendidikan formal peternak cukup beragam, mulai dari tingkat pendidikan formal yang terendah (tidak sekolah) sampai tingkat pendidikan tertinggi (S1). Dan di KUNAK KPS Bogor ini ternyata banyak peternak yang tingkat pendidikannya sampai SD yaitu sebanyak 12 responden atau sebesar 37 persen.

Tabel 3. Jumlah dan Persentase Responden Menurut Tingkat Pendidikan Formal

\begin{tabular}{lccc}
\hline $\begin{array}{l}\text { Tingkat } \\
\text { dikan }\end{array}$ & Pendi- & $\begin{array}{c}\text { Jumlah Re- } \\
\text { sponden }\end{array}$ & Persentase \\
\hline \multicolumn{2}{l}{ Tidak sekolah } & 2 & 6 \\
Sekolah & Dasar & 12 & 37 \\
(SD) & & & \\
SMP & 5 & 16 \\
SMA & 7 & 22 \\
S1 & 6 & 19 \\
Total & 32 & 100 \\
\hline
\end{tabular}

Para peternak sapi perah di Kawasan Usaha Peternakan (KUNAK) KPS Bogor ini ada yang pernah mengikuti pelatihan ada juga yang belum, sebagian besar peternak yang pernah mengikuti pelatihan atau kursus adalah peternak yang aktif mengikuti setiap kegiatan yang diadakan oleh koperasi.

Tabel 4. Jumlah dan Persentase Responden Menurut Keikutsertaan Pelatihan

\begin{tabular}{|c|c|c|}
\hline Pelatihan/Kursus & $\begin{array}{l}\text { Jumlah respon- } \\
\text { den }\end{array}$ & Persentase \\
\hline Pernah mengikuti & 14 & 44 \\
\hline $\begin{array}{l}\text { Tidak pernah mengi- } \\
\text { kuti }\end{array}$ & 18 & 56 \\
\hline Total & 32 & 100 \\
\hline
\end{tabular}

\section{Sapi Perah}

Tabel 5. Jumlah dan Persentase Responden Menurut Jumlah Sapi Perah yang Dirawat

\begin{tabular}{lcc}
\hline $\begin{array}{l}\text { Jumlah Sapi Per- } \\
\text { ah }\end{array}$ & Jumlah responden & Persentase \\
\hline$\leq 11$ ekor & 7 & 22 \\
12 ekor -18 ekor & 9 & 28 \\
$\geq 19$ ekor & 16 & 50 \\
Total & 32 & 100 \\
\hline
\end{tabular}

Sebagian besar peternak sapi perah merawat lebih dari 19 ekor sapi perah, namun kenyataan yang terjadi di lapang, ternyata banyak rumah tangga peternak yang hanya berstatus sebagai buruh peternakan, sehingga sapi- sapi yang ada adalah sapi milik bos (investor) para rumah tangga peternak sapi perah tersebut.

\section{STATUS PEKERJAAN DAN STRATEGI NAFKAH RUMAH TANGGA PADA PETERNAKAN SAPI PERAH KAWASAN USAHA PETERNAKAN KPS BOGOR}

\section{Livelihood Asset}

Livelihood Asset adalah keseluruhan modal (baik modal yang sudah ada maupun modal yang diusahakan) yang kemudian dimanfaatkan oleh peternak untuk menjalankan atau mengembangkan strategi nafkahnya. Menurut Ellis (2000), Livelihood Asset terdiri dari modal alam, modal fisik, modal sumberdaya manusia, modal financial, dan modal sosial.

\section{Modal Alam}

Modal alam (natural capital) terdiri dari tanah, air, dan sumberdaya biologi yang di gunakan oleh manusia sebagai sarana bertahan hidup. Modal alam lebih banyak mengacu pada sumber daya lingkungan (environtmental resources) baik yang dapat diperbaharui atau tidak (Ellis 2000). Kondisi alam yang ada di KUNAK ini cukup mendukung untuk pengembangan usaha peternakan, dengan ketinggian tempat yang cukup, udaranya yang masih segar, masih banyaknya lahan yang ditumbuhi rumput-rumput.

Modal alam (natural capital) yang paling banyak dimanfaatkan oleh peternak sapi perah tentunya adalah rumput sebagai pakan sapi, sedangkan penggunaan air untuk peternak sapi perah di KUNAK ini sudah diatur oleh koperasi dengan sistem seperti air pam. Selain itu, ada juga beberapa peternak yang memanfaatkan gedeboh pisang dan daun jagung sebagai pakan tambahan apabila rumput yang didapat jumlahnya sedikit. Hal ini seperti diungkapkan oleh Bapak UN (42 tahun):

"Kalau untuk sapi, yang diambil dari alam hanya rumput aja neng, paling sama gedeboh pisang, itu juga jarang dikasihnya, soalnya kalau gedeboh pisang itu mengurangi produksi susu. Terus kalau lagi musim jagung, yah paling sama daun jagung juga. Kalau untuk air diambilnya dari koperasi dan kita bayar perbulan"

\section{Modal Fisik}

Modal fisik (Physical Capital) yang dimiliki oleh peternak sudah cukup memadai, dengan adanya sapi perah, kandang sapi perah, alat-alat produksi (ember, selang, milk can, sikat, dan lain-lain), rumah yang letaknya dekat dengan kandang, serta infrastruktur jalan yang cukup baik untuk mobilitas ekonomi. Waktu dulu alat-alat produksi yang peternak gunakan tersebut biasanya berasal dari koperasi namun untuk saat ini lebih banyak dari pasar, hal ini dikarenakan beberapa hal seperti ketika peternak mau membeli namun persediaan alat produksi tersebut sedang tidak ada, kemudian harganya yang lebih mahal jika dibandingkan dengan harga pasar.

Adapun beberapa peternak yang menggunakan mesin pemerah dan mesin pemotong rumput, biasanya peternak yang mempunyai mesin ini adalah peternak yang bekerja pada investor dan alat tersebut sudah disediakan oleh 
investornya. Tidak banyaknya peternak yang menggunakan alat-alat tersebut juga dikarenakan tidak praktisnya penggunaan alat tersebut, mereka beralasan bahwa lebih cepat dengan manual karena apabila menggunakan mesin pemerah, peternak harus tetap melakukan pemerahan secara manual (kerja dua kali). Selain alat-alat yang mendukung produksi, adapun modal fisik berupa mesjid yang biasa digunakan peternak untuk beribadah dan berkumpul bersama peternak lainnya dalam waktu-waktu tertentu misalnya pengajian.

\section{Modal Sumberdaya Manusia}

Modal sumberdaya manusia di KUNAK ini cukup rendah apabila dilihat dari pendidikan formal terakhir peternak sapi perahnya. Sebagian besar peternak adalah lulusan sekolah dasar bahkan ada yang tidak sekolah namun tidak dapat dipungkiri bahwa masih ada juga peternak yang lulusan S1. Meskipun banyak peternak yang pendidikan formalnya rendah, namun hal ini tidak membuat peternak berpikiran sempit karena mereka berusaha untuk mewujudkan pendidikan formal anak-anaknya yang lebih tinggi. Terbukti anak-anak dari para peternak tersebut sebagian besar masih sekolah dan tidak ada yang putus sekolah diusia sekolah. Seperti yang dituturkan oleh JYD (37 tahun) berikut:

$$
\begin{aligned}
& \text { “... yah sebagai orang tua tentunya ingin kalau } \\
& \text { anaknya bisa sekolah lebih tinggi dari orang } \\
& \text { tuanya, biar nanti kehidupannya gak kayak saya } \\
& \text { gini. Soalnya disini keliatan banget perbedaannya, } \\
& \text { contohnya Bapak X, dia mah seorang sarjana jadi } \\
& \text { aktif kemana-mana dan lebih tahu kalau ada apa- } \\
& \text { apa, nah kalau saya mah cuma bisa diem aja gara- } \\
& \text { gara gak tahu apa-apa....” }
\end{aligned}
$$

Selain itu, para peternak juga semangat untuk mengikuti pelatihan-pelatihan yang biasanya diadakan oleh koperasi. Hasil dari pelatihan tersebut peternak dijadikan modal untuk pengembangan usaha yang lebih baik kedepannya. Selain dari pelatihan-pelatihan, biasanya peternak juga belajar dari pengalaman-pengalaman sebelumnya karena selain ilmu pengetahun, dalam dunia peternakan juga diperlukan keahlian yang terkadang tidak didapatkan dari ilmu pengetahuan saja. Pengalaman-pengalaman itulah yang menjadi alasan para peternak masih bisa bertahan sampai sekarang.

\section{Modal Sosial}

Modal sosial (Social Capital) yang terbentuk di KUNAK KPS Bogor ini adalah jaringan antara peternak sapi perah atau investor dengan pihak koperasi, dimana pihak koperasi adalah pihak yang menampung hasil produksi susu dari para peternak. Kemudian jaringan antara pihak peternak dengan pemilik sapi perah (investor), dimana keduanya harus saling memberikan keuntungan. Adapun hubungan peternak dengan peternak lainnya, dimana biasanya mereka berkumpul untuk saling bertukar pikiran atau pengalaman demi terpeliharanya sapi perah yang lebih baik. Serta ada juga hubungan antara peternak dengan penjual pakan dan alat-alat produksi. Selain itu, ada juga norma atau aturan yang berlaku untuk menjaga agar jaringan yang terjalin tetap baik, aturan yang terdapat di KUNAK KPS Bogor ini sebagian besar tidak tertulis dan yang tertulis hanyalah aturan yang dikeluarkan oleh pihak koperasi untuk para anggotanya. Hal yang paling penting dalam mempertahankan jaringan yang baik ini adalah kepercayaan dari masing-masing individu yang terlibat, terutama kepercayaan antara bos (investor) dengan pegawainya. Seperti yang disampaikan oleh IHD (39 tahun) berikut:

“... Alhamdulillah kalau bos saya orangnya adil, jadi saya nyaman kerja sama dia. Buktinya saya bisa bertahan sampe 15 tahun sama bos yang ini, sebenarnya tinggal saling percaya aja. Ketika bos ngasih kepercayaan sama kita, yah kita berikan hasil yang memuaskan buat bos, dengan kayak gitu bisa bertahan ini usaha. Kan disini banyak juga para investor yang baru beberapa bulan udah bangkrut, yah kebanyakan itu gara-gara pegawainya kurang bisa dipercaya...."

\section{Modal Finansial}

Modal financial (financial capital and substitutes) yang dimiliki peternak sapi perah di KUNAK KPS Bogor ini terbilang sedang bahkan mendekati rendah karena hanya sebagian kecil peternak saja yang menyisihkan, menabungkan atau menginvestasikan uangnya. Peternak yang modal finansialnya rendah beralasan bahwa pendapatan yang didapatkan hanya habis untuk kebutuhan sehari-hari saja, jadi tidak ada sisa untuk ditabungkan. Meskipun mereka tidak menabung namun mereka (biasanya istri peternak) tetap melakukan kegiatan arisan yang biasanya dilaksanakan setiap seminggu sekali. Peternak dengan modal finansial sedang adalah para peternak yang melakukan investasi dalam bentuk warung, kendaraan, perhiasan serta sapi perah muda, namun sedikit yang menyimpan uang dalam bentuk tabungan. Biasanya peternak yang seperti ini adalah peternak yang ingin berusaha untuk menutupi penghasilan utama dan peternak yang mencari pemasukan tambahan. Dan peternak yang modal financialnya tinggi adalah peternak yang melakukan investasi dan mempunyai tabungan berupa uang baik di Bank maupun di rumah, kisaran jumlah tabungan peternak sapi perah ini antara Rp 500.000 sampai $\mathrm{Rp} 5000.000$.

\section{Status Pekerjaan}

Status pekerjaan yang ada di KUNAK KPS ini cukup beragam, namun penelitian ini hanya fokus pada tiga status pekerjaan yaitu peternak murni, buruh ternak, dan peternak/buruh ternak ditambah pekerjaan lain di luar peternakan. Peternak murni artinya sumber pendapatan yang didapatkan untuk memenuhi kebutuhan hidup rumah tangga sepenuhnya berasal dari hasil peternakan berupa susu dari sapi perah yang diternakan.

Tabel 6. Jumlah dan Persentase Rumah Tangga Menurut Bentuk Strategi Nafkah

\begin{tabular}{lcc}
\hline Status Pekerjaan & $\begin{array}{c}\text { Jumlah rumah } \\
\text { tangga }\end{array}$ & Persentase \\
\hline Peternak murni & 4 & 12 \\
Buruh ternak & 20 & 63 \\
Peternak/Buruh di- & & \\
tambah pekerjaan & 8 & 25 \\
lain diluar peternakan & 32 & 100 \\
Total & \\
\hline
\end{tabular}


Buruh ternak artinya sumber pendapatan yang didapatkan untuk memenuhi kebutuhan hidup rumah tangga berasal dari penghasilan atau gaji sebagai buruh peternakan. Peternak/Buruh ternak ditambah pekerjaan lain di luar peternakan artinya sumber pendapatan yang didapatkan berasal dari hasil peternak murni atau buruh ternak dan ditambah dari usaha lainnya di luar peternakan seperti berdagang (warung kecil-kecilan), menjadi pegawai, wiraswasta, pensiunan, serta guru.

Dari jumlah sampel rumah tangga peternak sapi perah yang ada di KUNAK KPS Bogor, Desa Situ Udik, didapatkan 4 rumah tangga peternak atau sebesar 12 persen berstatus peternak murni, 20 rumah tangga atau sebesar 63 persen berstatus buruh ternak dan 8 rumah tangga atau sebesar 25 persen berstatus peternak/buruh ternak ditambah pekerjaan lain di luar peternakan. Banyaknya rumah tangga dengan status pekerjaan buruh ternak di KUNAK KPS Bogor, Desa Situ Udik ini karena sebagian besar pemilik kavling merupakan para investor yang memperkerjakan buruh peternakan dengan sistem kepercayaan.

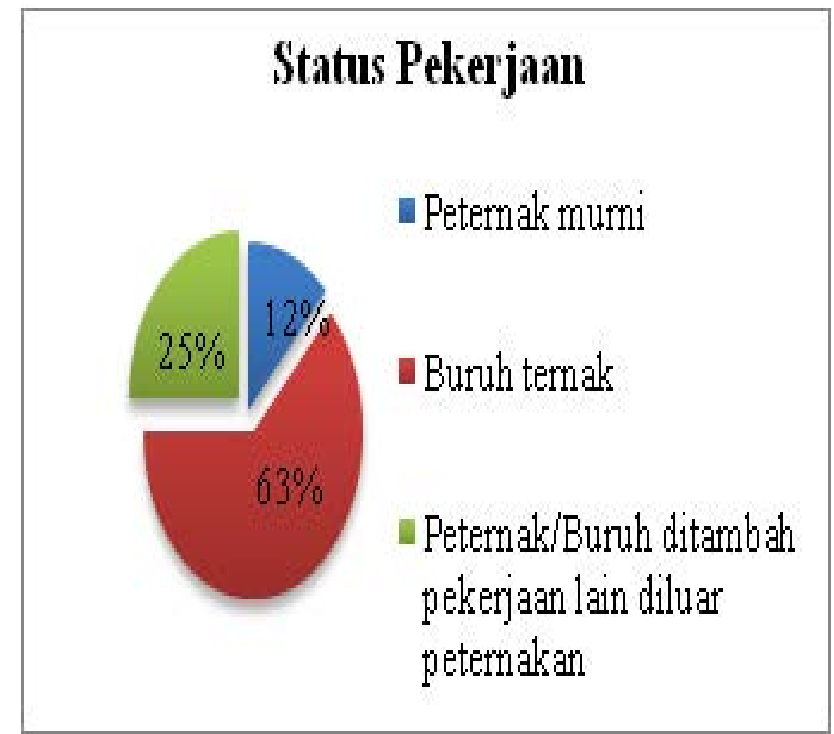

Gambar 1 Status Pekerjaan pada Peternakan Sapi Perah KUNAK

\section{Strategi Nafkah}

Kebutuhan hidup yang semakin meningkat dan resiko pekerjaan yang semakin banyak, mengharuskan para rumah tangga di peternakan KUNAK KPS Bogor ini melakukan strategi nafkah atau berbagai aktifitas yang mampu menunjang kebutuhan hidup tersebut. Strategi nafkah setiap rumah tangga peternak sapi perah tentunya akan beragam. Hal itu didasarkan pada kondisi karakteristik peternak sapi perah dan sumber daya yang ada, serta faktor lain yang mampu mempengaruhi keputusan peternak dalam menentukan strategi nafkahnya. Banyaknya resiko yang dihadapi oleh rumah tangga peternak sapi perah, seperti susahnya mencari pakan pada musim tertentu, semakin bertambah mahalnya harga konsentrat, dan adanya sapi perah yang sakit bahkan bisa sampai mati serta resikoresiko lainnya juga merupakan salah satu dari berbagai alasan rumah tangga melakukan strategi nafkah. Berikut akan dijelaskan lebih lanjut pada tabel 7 tentang hubungan antara status pekerjaan dengan strategi nafkah.
Tabel 7. Hubungan status pekerjaan dengan strategi nafkah

\begin{tabular}{|c|c|c|c|}
\hline & \multicolumn{3}{|c|}{ Strategi Nafkah } \\
\hline & $\begin{array}{l}\text { Pola nafkah } \\
\text { ganda }\end{array}$ & Migrasi & $\begin{array}{c}\text { Intensifikasi farm } \\
\text { (ternak) }\end{array}$ \\
\hline $\begin{array}{l}\text { Peternak } \\
\text { murni } \\
\text { (4 rumah } \\
\text { tangga) }\end{array}$ & $\begin{array}{l}\text { Ada } 2 \text { rumah } \\
\text { tangga: } \\
\text { biasanya kebu- } \\
\text { tuhan rumah } \\
\text { tangga dibantu } \\
\text { dengan istri } \\
\text { yang sama-sa- } \\
\text { ma bekerja. }\end{array}$ & $\begin{array}{l}\text { Ada satu rumah } \\
\text { tangga yang } \\
\text { meakukan } \\
\text { strategi ini. } \\
\text { Rumah tangga } \\
\text { ini sebelumnnya } \\
\text { berasal dari } \\
\text { daerah jawa } \\
\text { tengah, dan pin- } \\
\text { dah ke Kunak } \\
\text { dikarenakan } \\
\text { melanjutkan } \\
\text { peternakan } \\
\text { ayahnya. }\end{array}$ & $\begin{array}{l}\text { Hampir } 100 \\
\text { persen rumaah } \\
\text { tangga melaku- } \\
\text { kannya. Biasanya } \\
\text { para rumah } \\
\text { tamgga melaku- } \\
\text { kan pemilihan } \\
\text { sapi yang lebih } \\
\text { unggul, memilih } \\
\text { konsentrat yang } \\
\text { kualitasnya paling } \\
\text { bagus, melaku- } \\
\text { kan perawatan } \\
\text { yang lebih dari } \\
\text { biasanya. }\end{array}$ \\
\hline $\begin{array}{l}\text { Buruh } \\
\text { ternak (20 } \\
\text { rumahah } \\
\text { tangga) }\end{array}$ & $\begin{array}{l}\text { Ada } 6 \text { rumah } \\
\text { tangga: bi- } \\
\text { asanya rumah } \\
\text { tangga bekerja } \\
\text { sampingan } \\
\text { dengan men- } \\
\text { jadi pengantar } \\
\text { susu atau istri } \\
\text { dan anaknya } \\
\text { juga ikut } \\
\text { bekerja. }\end{array}$ & $\begin{array}{l}\text { Semuanya mer- } \\
\text { upakan perantau } \\
\text { dari berbagai } \\
\text { daerah, sebagian } \\
\text { ada yang sudah } \\
\text { menetap men- } \\
\text { jadi penduduk } \\
\text { KUNAK, } \\
\text { namun sebagian } \\
\text { lagi tetap ber- } \\
\text { status perantau. } \\
\text { Alasan rumah } \\
\text { tangga melaku- } \\
\text { kan strategi ini } \\
\text { biasanya karena } \\
\text { diajak oleh } \\
\text { atasannya atau } \\
\text { sebelumnya su- } \\
\text { dah ada keluarga } \\
\text { yang bekerja. }\end{array}$ & $\begin{array}{l}\text { Hampir } 90 \text { persen } \\
\text { rumah tangga } \\
\text { melakukannya. } \\
\text { Biasanya mereka } \\
\text { melakukan in- } \\
\text { tensifikasi farm } \\
\text { atas perintah dari } \\
\text { atasannya. }\end{array}$ \\
\hline $\begin{array}{l}\text { Peternak/ } \\
\text { buruh ternak } \\
\text { + Usaha lain } \\
\text { ( } 8 \text { rumah } \\
\text { tangga) }\end{array}$ & $\begin{array}{l}\text { Semuanya } \\
\text { melakukanan } \\
\text { pola natkah } \\
\text { ganda dengan } \\
\text { melakukan } \\
\text { pekeriaan } \\
\text { lain diluar } \\
\text { pekerjaan } \\
\text { utamanyya, sep- } \\
\text { erti berdagang, } \\
\text { pengantar } \\
\text { susu dan yang } \\
\text { lainnya. }\end{array}$ & $\begin{array}{l}\text { Ada } 5 \text { rumah } \\
\text { tangga yang } \\
\text { melakukan } \\
\text { migrasi. }\end{array}$ & $\begin{array}{l}\text { Hanya } 50 \text { persen } \\
\text { yang melaku- } \\
\text { kan strategi ini. } \\
\text { Alasan tidak } \\
\text { melakukan strate- } \\
\text { gi ini biasanya } \\
\text { karena kurangnya } \\
\text { modal. }\end{array}$ \\
\hline
\end{tabular}

\section{TINGKAT KESEJAHTERAAN RUMAH TANGGA DI PETERNAKAN SAPI PERAH}

Tingkat kesejahteraan rumah tangga dalam penelitian ini dilihat dari beberapa indikator, yaitu tingkat pendapatan, tingkat pendidikan, tingkat kesehatan, kondisi perumahan, akses terhadap pelayanan kesehatan, dan tingkat partisipasi dalam kegiatan publik. Dari indikator-indikator tersebut didapatkan hasil bahwa tingkat kesejahteraan rumah tangga pada peternakan sapi perah KUNAK KPS Bogor tergolong cukup tinggi dengan adanya 20 rumah tangga atau sebesar 63 persen yang tingkat kesejahteraan rumah tangganya tinggi dan sebanyak 12 rumah tangga atau sebesar 37 persen dengan tingkat kesejahteraan rumah tangga sedang.

Hasil penelitian ini berarti sesuai dengan data sekunder Desa Situ Udik pada tahun 2013 yang menyebutkan bahwa "Tingkat ekonomi masyarakat Desa Situ Udik tidaklah merata di setiap wilayah atau kampung. Kp. Kunak I merupakan wilayah yang paling tinggi tingkat ekonominya dibandingkan dengan wilayah lain, hal ini dikarenakan di Kp. Kunak I terdapat salah satu peternakan sapi perah terbesar di Kabupaten Bogor, Tidak hanya itu, Kp. Kunak I juga merupakan ibukota Desa Situ Udik sehingga jalan menuju kantor Desa Situ Udik yang kondisinya baik sehingga akses transportasi untuk pertumbuhan ekonomi sangatlah mudah". 
Tabel 8. Jumlah dan Presentase Rumah Tangga Menurut Tingkat Kesejahteraan

\begin{tabular}{|c|c|c|c|}
\hline $\begin{array}{l}\text { Tingkat } \\
\text { jahteraan }\end{array}$ & kese- & $\begin{array}{c}\text { Jumlah } \\
\text { rumah tangga }\end{array}$ & Persentase \\
\hline Rendah & & 0 & 0 \\
\hline Sedang & & 12 & 37 \\
\hline Tinggi & & 20 & 63 \\
\hline Total & & 32 & 100 \\
\hline
\end{tabular}

Dengan tingkat ekonominya yang tinggi karena akses transportasi untuk pertumbuhan ekonomi sangat mudah maka dapat dijadikan salah satu indikator yang akan berdampak pada kesejahteraan keluarga. Namun hasil melalui pendekatan kuantitatif ini tidak sama dengan hasil melalui pendekatan kualitatif. Hasil dari pendekatan kualitatif menunjukkan bahwa hampir seluruh rumah tangga peternak merasa belum termasuk keluarga sejahtera. Hasil tersebut dibuktikan ketika digambarkan dalam tangga kesejahteraan hampir sebagian besar rumah tangga memilih tangga kesejahteraan 3 ke bawah, alasannya dikarenakan masih merasa serba kekurangan.

\section{Tingkat Pendapatan}

Tingkat pendapatan dalam penelitian ini dilihat dari seluruh akumulasi keuntungan yang diperoleh dari usaha peternakan selama satu bulan terakhir seperti jumlah produksi susu, upah bulanan atau ditambah dengan pemasukan usaha tambahan lainnya. Selain itu, pendapatan yang diambil dalam penelitian ini adalah pendapatan yang belum dikurangi oleh biaya produksi dan konsumsi sehingga angka nominalnya terlihat cukup besar. Hasil penelitian menunjukkan bahwa terdapat 13 rumah tangga atau sebesar 40 persen tergolong pada tingkat pendapatan rendah yaitu kurang dari $\mathrm{Rp} 1.710 .577$, kemudian 14 rumah tangga atau sebesar 44 persen tergolong pada tingkat pendapatan sedang yaitu antara $\mathrm{Rp} 1.710 .577$ sampai $\mathrm{Rp}$ 16.752.712, dan 5 rumah tangga atau sebesar 16 persen tergolong pada tingkat pendapatan tinggi yaitu lebih dari Rp 16.752.712. Dari hasil tersebut maka dapat disimpulkan bahwa tingkat pendapatan rumah tangga peternak sapi perah di KUNAK KPS Bogor ini tergolong sedang.

Tabel 9. Jumlah dan Persentase Rumah Tangga Menurut Tingkat Pendapatan (bulan)

\begin{tabular}{lcc}
\hline Tingkat pendapatan & $\begin{array}{c}\text { Jumlah } \\
\text { rumah tangga }\end{array}$ & Persentase \\
\hline$<$ Rp1 710 577 & 13 & 40 \\
Rp1 710 577 - Rp 16 & 14 & 44 \\
752712 & & \\
$>$ Rp16 752 712 & 5 & 16 \\
Total & 32 & 100 \\
\hline
\end{tabular}

\section{Tingkat pendidikan}

Penentuan tingkat pendidikan rumah tangga peternak sapi perah mengacu pada BPS yaitu dilihat dari pendidikan formal terakhir yang ditamatkan oleh anggota keluarga peternak yang berumur 10 tahun ke atas, hal ini dilakukan untuk melihat kualitas sumberdaya manusia secara lebih spesifik. Berdasarkan data yang diperoleh didapatkan bahwa sebagian besar tingkat pendidikan istri peternak adalah Sekolah Dasar namun ada juga yang tingkat pendidikannya sampai D3/S1. Sedangkan untuk tingkat pendidikan anak-anaknya apabila mengacu pada BPS maka hasilnya tidak dapat disimpulkan secara pasti, karena sebagian besar anak dari rumah tangga peternak masih berusia muda (masih sekolah) dan ada juga yang belum sekolah. Adapun tiga rumah tangga peternak yang anaknya sudah menamatkan pendidikan terakhirnya, dan tingkat pendidikan yang ditamatkannya pun beragam, mulai dari SD sampai Sarjana.

Tabel 10. Tingkat Pendidikan Rumah Tangga Peternak Sapi Perah

\begin{tabular}{|c|c|c|c|c|}
\hline $\begin{array}{l}\text { Tingkat pendi- } \\
\text { dikan }\end{array}$ & Suami & Istri & Anak & $\begin{array}{l}\text { Lainn- } \\
\text { ya* }\end{array}$ \\
\hline Tidak sekolah & 2 & 4 & - & 2 \\
\hline SD & 12 & 10 & 1 & 1 \\
\hline SMP & 5 & 7 & 1 & 1 \\
\hline SMA & 7 & 3 & - & 4 \\
\hline D3/S1 & 6 & 5 & 1 & - \\
\hline \multicolumn{5}{|c|}{$\begin{array}{l}\text { *yang menjadi tanggungan rumah tangga (di luar keluarg } \\
\text { inti) }\end{array}$} \\
\hline \multicolumn{5}{|c|}{$\begin{array}{l}\text { Hasil penelitian menunjukkan bahwa terdapat } 16 \text { rumal } \\
\text { tangga atau sebesar } 50 \text { persen tingkat pendidikan rumal } \\
\text { tangganya tergolong rendah, kemudian } 9 \text { rumah tangga ata } \\
\text { sebesar } 28 \text { persen tergolong pada tingkat pendidikan sedang } \\
\text { dan } 7 \text { rumah tangga atau sebesar } 22 \text { persen tergolong pad } \\
\text { tingkat pendidikan tinggi. Banyaknya rumah tangga yang } \\
\text { tergolong tingkat pendidikan rendah dikarenakan beberaps } \\
\text { faktor, seperti tingkat pendidikan peternak dan istri dar } \\
\text { peternak memang rendah dan tidak semua rumah tangga } \\
\text { peternak mempunyai anak berumur } 10 \text { tahun keatas yang } \\
\text { sudah menamatkan pendidikan formalnya. }\end{array}$} \\
\hline
\end{tabular}

Tabel 11. Jumlah dan Persentase Rumah Tangga Menurut Tingkat Pendidikan

\begin{tabular}{|c|c|c|c|}
\hline $\begin{array}{l}\text { Tingkat } \\
\text { dikan }\end{array}$ & pendi- & $\begin{array}{c}\text { Jumlah } \\
\text { rumah tangga }\end{array}$ & Persentase \\
\hline Rendah & & 16 & 50 \\
\hline Sedang & & 9 & 28 \\
\hline Tinggi & & 7 & 22 \\
\hline Total & & 32 & 100 \\
\hline
\end{tabular}

\section{Tingkat Kesehatan}

Tingkat kesehatan yang dilihat dalam penelitian ini adalah tingkat kesehatan responden beserta anggota rumah tangganya. Tingkat kesehatan rumah tangga ini diukur dari banyaknya responden atau anggota rumah tangga yang mengalami gangguan kesehatan selama sebulan yang lalu dan setahun terakhir, atau kalaupun tidak sakit namun suka melakukan pemeriksaan kesehatan/KB. Hasil penelitian menunjukkan bahwa terdapat 16 rumah tangga atau 
sebesar 38 persen tergolong rumah tangga yang tingkat kesehatannya rendah, lalu 17 rumah tangga atau sebesar 53 persen tergolong rumah tangga yang tingkat kesehatannya sedang, dan 3 rumah tangga atau sebesar 9 persen tergolong rumah tangga yang tingkat kesehatannya tinggi.

Tabel 12. Jumlah dan Persentase Rumah Tangga Menurut Tingkat Kesehatan

\begin{tabular}{|c|c|c|c|}
\hline $\begin{array}{l}\text { Ting kat } \\
\text { kesehatan }\end{array}$ & $\begin{array}{c}\text { Jumlah } \\
\text { rumah } \\
\text { tangga }\end{array}$ & $\begin{array}{l}\text { Persen- } \\
\text { tase }\end{array}$ & Keterangan \\
\hline Rendah & 12 & 38 & $\begin{array}{l}\text { Dikatakan rendah } \\
\text { karena dalam sebulan } \\
\text { yang lalu dan setahun } \\
\text { terakhir ada anggota } \\
\text { rumah tangga yang } \\
\text { sakit serta tidak ada } \\
\text { yang melakukan KB. }\end{array}$ \\
\hline Sedang & 17 & 53 & $\begin{array}{l}\text { Dikatakan sedang } \\
\text { karena anggota } \\
\text { rumah tangga hanya } \\
\text { sakit disalah satu } \\
\text { waktu saja, dan ada } \\
\text { anggota rumah tang- } \\
\text { ga yang mengikuti } \\
\text { KB }\end{array}$ \\
\hline Tinggi & 3 & 9 & $\begin{array}{l}\text { Dikatakan tinggi } \\
\text { karena dalam sebulan } \\
\text { yang lalu dan setahun } \\
\text { terakhir tidak ada an- } \\
\text { ggota rumah tangga } \\
\text { yang sakit serta ada } \\
\text { yang melakukan KB }\end{array}$ \\
\hline Total & 32 & 100 & \\
\hline
\end{tabular}

Tingkat kesehatan rumah tangga peternak sapi perah sebagian besar tergolong pada tingkat yang sedang. Hal ini terjadi karena para peternak ataupun anggota keluarganya jarang mengalami sakit. Sedangkan untuk rumah tangga yang tingkat kesehatannya rendah tidak hanya disebabkan oleh seringnya peternak atau anggota rumah tangganya sakit, namun dalam penelitian ditemukan faktor lain yang memengaruhinya yaitu tidak semua rumah tangga peternak (khususnya istri dari peternak) mengikuti KB, dan adapun alasan mengapa tidak mengikuti $\mathrm{KB}$ adalah karena sengaja tidak mengikuti, sedang hamil, dan sudah lanjut usia. Jenis penyakit yang biasanya diderita rumah tangga peternak sapi perah di KUNAK KPS Bogor ini adalah deman, flu atau batuk.

\section{Kondisi Perumahan (Tempat Tinggal)}

Perumahan atau tempat tinggal rumah tangga adalah tempat berkumpulnya keluarga dan berfungsi sebagai tempat berlindung. Namun merurut BPS dalam Raya (2001), pada saat ini rumah tidak hanya berfungsi sebagai tempat berlindung tetapi sudah menjadi bagian dari gaya hidup, dan menunjukkan identitas pemiliknya. Kualitas rumah tinggal dan fasilitas yang digunakan dalam kehidupan seharihari mencerminkan tingkat kesejahteraan penghuninya. Menurut kriteria rumah sehat agar penghuninya dapat hidup nyaman tidak berdesakan, maka minimal luas lantai per anggota rumah tangga adalah $9 \mathrm{~m} 2$. Sedangkan fasilitas pokok yang penting agar suatu rumah menjadi nyaman dan sehat untuk ditinggali antara lain adalah tersedianya listrik dan air bersih.

Kondisi perumahan rumah tangga peternak sapi perah di KUNAK KPS Bogor termasuk dalam kategori layak untuk dihuni karena kondisi rumah tempat tinggal keluarga mempunyai atap, lantai dan dinding dalam kondisi yang layak ditempati, baik dari segi perlindungan maupun dari segi kesehatan. Selain itu, ada juga fasilitas listrik dan air bersih serta fasilitas pendukung lainnya seperti asset rumah tangga misalnya televisi, kulkas, kipas angin, dan lain-lain.

Tabel 13. Jumlah Rumah Tangga Menurut Indikator Kondisi Perumahan

\begin{tabular}{|c|c|c|}
\hline $\begin{array}{l}\text { Kondisi Perumah- } \\
\text { an (tempat tinggal) } \\
\text { peternak }\end{array}$ & Keterangan & $\begin{array}{l}\text { Jumlah } \\
\text { rumah tangga }\end{array}$ \\
\hline $\begin{array}{l}\text { Status kepemilikan } \\
\text { rumah }\end{array}$ & $\begin{array}{l}\text { - Milik orang } \\
\text { tua/investor } \\
\text { - Sewa } \\
\text { - Milik sendiri }\end{array}$ & $\begin{array}{c}23 \\
0 \\
9\end{array}$ \\
\hline Atap rumah & $\begin{array}{l}\text { - Tanpa atap } \\
\text { - Dengan seng/ } \\
\text { asbes } \\
\text { - Dengan gen- } \\
\text { teng }\end{array}$ & $\begin{array}{c}0 \\
25 \\
7\end{array}$ \\
\hline Dinding rumah & $\begin{array}{l}\text { - Kayu/bambu } \\
\text { - Setengah tem- } \\
\text { bok } \\
\text { - Tembok }\end{array}$ & $\begin{array}{c}0 \\
0 \\
32\end{array}$ \\
\hline Lantai rumah & $\begin{array}{l}\text { - Tanah } \\
\text { - Semen } \\
\text { - Keramik }\end{array}$ & $\begin{array}{c}0 \\
14 \\
18\end{array}$ \\
\hline $\begin{array}{l}\text { Aktivitas mandi, } \\
\text { cuci, kakus dilaku- } \\
\text { kan di: }\end{array}$ & $\begin{array}{l}\text { - Sungai } \\
\text { - Kamar mandi } \\
\text { umum } \\
\text { - Kamar mandi } \\
\text { sendiri }\end{array}$ & $\begin{array}{c}0 \\
5 \\
27\end{array}$ \\
\hline Luas rumah & 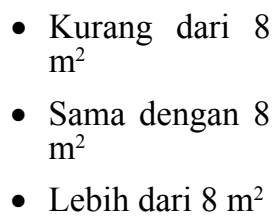 & $\begin{array}{c}0 \\
2 \\
30\end{array}$ \\
\hline
\end{tabular}

Hasil penelitian menunjukkan bahwa terdapat 31 rumah tangga atau sebesar 97 persen tergolong rumah tangga yang kondisi perumahannya layak untuk dihuni, namun ada satu rumah tangga atau sebesar 3 persen yang tergolong rumah tangga dengan kondisi perumahan cukup layak. Kondisi perumahan rumah tangga peternak sapi perah ini tergolong cukup layak karena lantai rumahnya yang masih memakai semen dan kurangnya fasilitas pendukung atau asset rumah tangga yang dimiliki. 


\section{Akses terhadap Pelayanan Kesehatan}

Akses terhadap pelayanan kesehatan dalam penelitian ini dilihat dari seberapa mudah rumah tangga memperoleh pelayanan kesehatan. Akses terhadap pelayanan kesehatan rumah tangga peternak sapi perah di KUNAK KPS Bogor tergolong mudah dengan jumlah rumah tangga 24 atau sebesar 75 persen dari 100 persen, sedangkan sebagian lagi tergolong dalam kategori sedang (kadang-kadang mudah, kadang-kadang sulit) dengan jumlah rumah tangga 8 atau sebesar 25 persen dari 100 persen.

Tabel 14. Jumlah dan Persentase Rumah Tangga Menurut Akses terhadap Pelayanan kesehatan

\begin{tabular}{lcc}
\hline Akses & $\begin{array}{c}\text { Jumlah rumah } \\
\text { tangga }\end{array}$ & Persentase \\
\hline Sulit & 0 & 0 \\
Sedang & 8 & 25 \\
Mudah & 24 & 75 \\
Total & 32 & 100 \\
\hline
\end{tabular}

Tabel 15. Jumlah Rumah Tangga Menurut Indikator Akses terhadap Pelayanan Kesehatan

\begin{tabular}{|c|c|c|}
\hline $\begin{array}{l}\text { Akses terhadap pe- } \\
\text { layanan kesehatan }\end{array}$ & Keterangan & $\begin{array}{l}\text { Jumlah } \\
\text { rumah } \\
\text { tangga }\end{array}$ \\
\hline \multirow[t]{3}{*}{$\begin{array}{l}\text { Perlakuan ketika } \\
\text { sakit }\end{array}$} & $\begin{array}{l}\text { - Dibiarkan sembuh } \\
\text { dengan sendirinya }\end{array}$ & 0 \\
\hline & $\begin{array}{l}\text { - Berobat dengan } \\
\text { obat warung }\end{array}$ & 7 \\
\hline & $\begin{array}{l}\text { - Pergi ke tempat pe- } \\
\text { layanan kesehatan }\end{array}$ & 25 \\
\hline \multirow{3}{*}{$\begin{array}{l}\text { Tempat pelayanan } \\
\text { kesehatan yang di- } \\
\text { tuju }\end{array}$} & - Puskesmas & 13 \\
\hline & - Rumah sakit & 4 \\
\hline & - Dokter & 15 \\
\hline \multirow[t]{2}{*}{ Alat transportasi } & - Umum & 6 \\
\hline & - Pribadi & 26 \\
\hline \multirow{2}{*}{$\begin{array}{l}\text { Kemudahan ru- } \\
\text { mah tangga dalam } \\
\text { mendapatkan akses } \\
\text { terhadap pelayanan } \\
\text { kesehatan }\end{array}$} & - Mudah & 32 \\
\hline & - Sulit & 0 \\
\hline \multirow[t]{3}{*}{ Pembayaran } & - Kasbon & 0 \\
\hline & - Askes & 2 \\
\hline & - Uang pribadi & 30 \\
\hline
\end{tabular}

Mudahnya rumah tangga peternak dalam mengakses pelayanan kesehatan karena mudahnya akses dan pelayanan untuk melakukan pengobatan, baik itu ke pelayanan kesehatan seperti dokter, puskesmas maupun rumah sakit. Sedangkan untuk rumah tangga responden yang masuk pada kategori sedang dikarenakan rumah tangga peternak ini apabila sakit jarang pergi ke tempat pelayanan kesehatan atau hanya mengonsumsi obat warung saja.

Alasannya karena penyakitnya tidak terlalu parah dan masih bisa disembuhkan dengan mengonsumsi obat warung, dan biasanya rumah tangga yang seperti ini akan pergi ke pelayanan kesehatan apabila penyakit yang diderita dianggap serius atau sudah parah. Gambarannya sebagaimana dipaparkan pada tabel 15 .

\section{Tingkat Partisipasi dalam Kegiatan Publik}

Tingkat partisipasi dalam kegiatan publik dilihat dari keikutsertaan seluruh atau sebagian dari anggota keluarga dalam kegiatan masyarakat di sekitarnya yang bersifat sosial kemasyarakatan, seperti gotong royong, ronda malam, rapat RT, arisan, pengajian, kegiatan PKK, kegiatan kesenian, olah raga dan sebagainya.

Hasil penelitian tingkat partisipasi dalam kegiatan publik ini menunjukkan bahwa 4 rumah tangga atau sebesar 12 persen tergolong dalam kategori rendah, 15 rumah tangga atau sebesar 47 persen tergolong dalam kategori sedang, dan 13 rumah tangga atau sebesar 41 persen tergolong dalam kategori tinggi. Rumah tangga peternak sapi perah di KUNAK KPS Bogor cukup aktif dalam mengikuti kegiatan-kegiatan yang ada di lingkungannya, kegiatan yang paling banyak diikuti adalah pengajian dan arisan.

Namun masih ada rumah tangga yang tingkat partisipasi dalam kegiatan publiknya rendah, hal ini dikarenakan berbagai alasan, salah satunya adalah karena waktu yang ada habis digunakan untuk mengurus sapi sehingga tidak ada waktu untuk mengikuti hal-hal seperti yang sudah disebutkan sebelumnya, kalaupun ada waktu luang maka waktu tersebut dimanfaatkan untuk beristirahat.

Tabel 16. Jumlah dan Persentase Rumah Tangga Menurut Tingkat Partisipasi dalam Kegiatan Publik

\begin{tabular}{lrr}
\hline Tingkat partisipasi & $\begin{array}{c}\text { Jumlah rumah } \\
\text { tangga }\end{array}$ & Persentase \\
\hline Rendah & 4 & 12 \\
Sedang & 15 & 47 \\
Tinggi & 13 & 41 \\
Total & 32 & 100 \\
\hline
\end{tabular}

Kenyataan di lapang pada penelitian ini menunjukkan bahwa kegiatan yang disebutkan sebelumnya tidak seluruhnya ada di KUNAK KPS Bogor. Kegiatan sosial kemasyarakatan yang ditemukan di KUNAK KPS Bogor ini ada arisan, pengajian, kumpul anggota kelompok peternak sapi perah, dan kegiatan memperingati hari besar islam.

\section{PENGARUH STATUS PEKERJAAN TERHADAP TINGKAT KESEJAHTERAAN RUMAH TANGGA PADA PETERNAKAN SAPI PERAH}

Status pekerjaan pada peternakan sapi perah di KUNAK KPS Bogor meliputi peternak murni, buruh ternak, peternak/ buruh ternak ditambah pekerjaan lain di luar peternakan. Ketiga status pekerjaan ini kemudian diuji pengaruhnya terhadap tingkat kesejahteraan rumah tangga yang terbagi menjadi enam variabel, yaitu tingkat pendapatan, tingkat pendidikan, tingkat kesehatan, kondisi perumahan, akses terhadap pelayanan kesehatan, dan tingkat partisipasi dalam kegiatan publik. Data yang didapat dianalisis dengan 
menggunakan tabel tabulasi silang. Pengujian dilakukan tentunya untuk mengetahui pengaruh status pekerjaan terhadap tingkat kesejahteraan rumah tangga pada peternakan sapi perah. Pengaruh status pekerjaan terhadap tingkat kesejahteraan rumah tangga pada peternakan sapi perah dianalisis dengan menggunakan SPSS for Windows versi 17 dengan model uji regresi linear berganda.

Tingkat kesejahteraan rumah tangga di peternakan sapi perah KUNAK KPS Bogor yang tinggi tersebut akan dijelaskan secara lebih rinci berdasarkan hasil analisis data yang disajikan pada tabel 28 .

Tabel 17 Jumlah dan Persentase Rumah Tangga Menurut Status Pekerjaan dan Tingkat Kesejahteraan

\begin{tabular}{lcccccc}
\hline $\begin{array}{l}\text { Tingkat } \\
\text { Kese- } \\
\text { jahteraan }\end{array}$ & \multicolumn{5}{c}{ Status Pekerjaan } \\
\cline { 2 - 7 } & $\begin{array}{l}\text { Peternak } \\
\text { murni }\end{array}$ & $\begin{array}{l}\text { Buruh } \\
\text { ternak }\end{array}$ & $\begin{array}{l}\text { Peternak/buruh } \\
\text { ternak ditam- } \\
\text { bah pekerjaan } \\
\text { lain di luar } \\
\text { peternakan }\end{array}$ \\
\cline { 2 - 7 } & $\mathrm{n}$ & $\%$ & $\mathrm{n}$ & $\%$ & $\mathrm{n}$ & $\%$ \\
\hline Rendah & 0 & 0 & 0 & 0 & 0 & 0 \\
Sedang & 0 & 0 & 12 & 60 & 0 & 0 \\
Tinggi & 4 & 100 & 8 & 40 & 8 & 100 \\
Total & 4 & 100 & 20 & 100 & 8 & 100 \\
\hline
\end{tabular}

Hasil penelitian menunjukkan bahwa rumah tangga dengan status pekerjaan peternak murni berada pada kategori tingkat kesejahteraan tinggi yaitu sebesar 100 persen. Hal yang sama juga terjadi pada rumah tangga dengan status pekerjaan peternak/buruh ternak ditambah pekerjaan lain di luar peternakan yang tingkat kesejahteraannya tinggi sebesar 100 persen. Sedangkan untuk status pekerjaan buruh ternak hanya 40 persen saja yang masuk kategori tingkat kesejahteraan tinggi dan sisanya masuk pada rumah tangga dengan tingkat kesejahteraan sedang yaitu sebesar 60 persen. Namun secara kualitatif hasil tentang kesejahteraan rumah tangga di peternakan sapi perah cukup berbeda, sebagian besar rumah tangga masih merasa bahwa tingkat kesejahteraan rumah tangganya belum terlalu sejahtera atau tinggi. Terutama untuk peternak dengan status pekerjaan buruh ternak hampir 80 persen menyatakan bahwa mereka masih belum sejahtera.

Data hasil penelitian ini kemudian diuji menggunakan uji statistik tabel anova (Uji F) dengan perangkat lunak SPSS. Uji F ini sekaligus akan menguji hipotesis penelitian sebagai berikut:

- $\quad \mathrm{H} 0$ : status pekerjaan tidak mempengaruhi tingkat kesejahteraan rumahtangga peternak sapi perah

- H1 : status pekerjaan mempengaruhi tingkat kesejahteraan rumahtangga peternak sapi perah

Hipotesis tersebut diuji dengan melihat nilai signifikansi ( $\mathrm{P}$ Value), jika (P Value) $<0,05$ maka $\mathrm{H} 0$ ditolak dan $\mathrm{H} 1$ diterima. Namun jika (P Value) $>0,05$ maka H0 diterima dan H1 ditolak. Dari hasil Uji F pada penelitian ini didapatkan nilai $\mathrm{F}$ hitung sebesar 16,821 dengan angka signifikansi (P Value) sebesar 0,000. Dengan tingkat signifikansi 95\% $(\alpha=0,05)$, maka angka signifikansi ( $\mathrm{P}$ Value) sebesar $0,000<0,05$, sehingga dari perbandingan tersebut dapat disimpulkan bahwa $\mathrm{H} 0$ ditolak dan $\mathrm{H} 1$ diterima atau berarti status pekerjaan memengaruhi tingkat kesejahteraan rumah tangga di peternakan sapi perah.

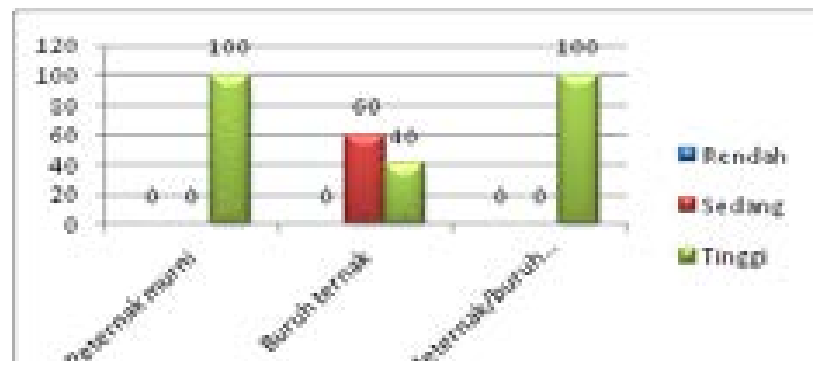

Gambar 2. Persentase Tingkat Kesejahteraan Berdasarkan Status Pekerjaan

\section{SIMPULAN}

Status pekerjaan yang ada di Kawasan Usaha Peternakan (KUNAK) KPS Bogor, Desa Situ Udik digolongkan menjadi tiga. Pertama, status pekerjaan peternak murni yaitu status pekerjaan yang seluruh sumber pendapatannya berasal dari hasil peternakan berupa susu dari sapi perah yang diternakan. Kedua, status pekerjaan buruh ternak yaitu status pekerjaan yang seluruh sumber pendapatannya berasal dari penghasilan atau gaji sebagai buruh peternakan. Dan ketiga, status pekerjaan peternak/buruh ternak ditambah pekerjaan lain di luar peternakan yaitu seluruh sumber pendapatannya berasal dari hasil peternak murni atau buruh ternak ditambah dari usaha lainnya di luar peternakan seperti berdagang (warung kecil-kecilan), pegawai koperasi, pegawai swasta, wiraswasta, pensiunan, serta guru. Dalam penelitian ini, sebagian besar rumah tangga tergolong pada status pekerjaan buruh ternak dengan jumlah 20 responden, sedangkan yang tergolong peternak murni hanya 4 responden, dan 8 responden yang tergolong peternak/buruh ternak ditambah pekerjaan lain di luar peternakan. Banyaknya peternak yang tergolong pada status pekerjaan buruh ternak dikarenakan di KUNAK KPS Bogor tersebut lebih banyak investornya dibandingkan peternak asli, sehingga kebanyakan rumah tangga disana hanya berstatus sebagai buruh atau pegawai peternakan yang di kontrak oleh para investor. Strategi nafkah rumah tangga pada peternakan sapi perah ini cukup beragam, mulai dari pola nafkah ganda, seperti melakukan banyak pekerjaan atau adanya keikutsertaan anggota rumah tangga yang lain dalam proses beternak, misalnya istri atau anak membantu membersihkan kandang atau memberi pakan atau memerah susu. Adapun intensifikasi farm (ternak), seperti usaha-usaha para rumah tangga untuk mengupayakan agar sapi dan hasil produksinya (susu sapi) mempunyai kualitas yang tinggi, sehingga harga jualnya mahal. Selain itu, ada juga migrasi, hampir seluruh rumah tangga di KUNAK KPS adalah imigran (migrasi dari daerah asal ke daerah KUNAK KPS), namun sebagian besar memilih menetap menjadi warga asli di KUNAK tersebut.

Tingkat kesejahteraan rumah tangga pada peternakan sapi perah KUNAK KPS Bogor berdasarkan pendekatan kuantitatif tergolong tinggi yaitu sekitar 63 persen, hasil ini ternyata tidak sesuai apabila dibandingkan dengan pendekatan kualitatif. Berdasarkan pendekatan kualitatif, hampir seluruh rumah tangga masih merasa kekurangan 
dan hanya sedikit yang mengatakan sudah sejahtera dan berkecukupan. Perbedaan ini dikarenakan berbedanya pandangan masing-masing rumah tangga terhadap pengertian tingkat kesejahteraan itu sendiri.

Status pekerjaan pada peternakan sapi perah memiliki pengaruh terhadap tingkat kesejahteraan rumah tangga. Berdasarkan pendekatan kuantitatif didapatkan hasil bahwa rumah tangga dengan status pekerjaan peternak/buruh ternak ditambah pekerjaan lain di luar peternakan memiliki tingkat kesejahteraan yang lebih tinggi jika dibandingkan dengan bentuk yang lainnya, namun berdasarkan pendekatan kualitatif didapatkan hasil yang berbeda yaitu hampir seluruh rumah tangga dengan status pekerjaan apapun berada pada tingkat kesejahteraan yang sedang bahkan rendah, dengan alasan masih merasa kekurangan.

Secara umum, status pekerjaan mampu mempengaruhi tingkat kesejahteraan rumah tangga di peternakan sapi perah KUNAK KPS Bogor, namun setelah dijabarkan, ternyata tidak semua variabel kesejahteraan dipengaruhi oleh status pekerjaan, variabel yang tidak terpengaruhi tersebut adalah tingkat kesehatan, kondisi perumahan, dan akses terhadap pelayanan kesehatan. Variabel tingkat kesehatan tidak terpengaruhi karena kesehatan individu tergantung pada daya tahan tubuh individu masing-masing, tidak membeda-bedakan status sosial. Kemudian variabel kondisi perumahan juga tidak terpengaruhi karena dalam kasus ini, semua rumah tangga mempunyai rumah yang kondisinya layak untuk dihuni, walaupun sebagian besar status perumahannya adalah bukan milik pribadi (fasilitas dari investor). Selain itu, variabel akses terhadap pelayanan kesehatan juga tidak terpengaruhi karena dalam kasus ini setiap rumah tangga mempunyai hak dan kemudahan untuk mendapatkan akses pelayanan kesehatan.

\section{SARAN}

Peternakan sapi perah yang sangat berpotensi untuk dikembangkan dengan susu sebagai komoditas yang berorientasi kepada pasar tentunya akan memberikan pengaruh yang besar terhadap perekonomian negara. Status pekerjaan pada peternakan sapi perah KUNAK yang saling melengkapi serta strategi nafkah rumah tangga pada peternakan sapi perah yang tidak hanya dilakukan untuk memenuhi kebutuhan hidupnya namun juga untuk tetap tersedianya kebutuhan susu dalam negeri, seharusnya mendapatkan dukungan dan perhatian yang lebih dari berbagai pihak yang terkait, dalam hal ini adalah pemerintah. Oleh karena itu, kebijakan pemerintah sebaiknya tidak hanya fokus pada komoditasnya saja namun juga fokus kepada para pelaku peternakannya (rumah tangga pada peternakan sapi perah). Hal tersebut dilakukan agar kehidupan para pelaku peternakan dapat terjamin dan tingkat kesejahteraannya dapat semakin meningkat.

\section{DAFTAR PUSTAKA}

Dharmawan AH. 2006. Sistem Penghidupan dan Nafkah Pedesaan Pandangan Sosiologi Nafkah (Livelihood Sociology) Mazhab Barat dan Mazhab Bogor. Sodality: Jurnal Transdisiplin Sosiologi, Komunikasi, dan Ekologi Manusia. Vol. 01, No.02 Agustus 2007.

Haloho RD, Santoso SI, Marzuki S. 2013.Analisis Profitabilitas pada Usaha Peternakan Sapi Perah di Kabupaten Semarang. [internet]. Jurnal Pengembangan Humaniora Vol. 13 No. 1. [diunduh 2014 Mar 2]. Terdapat pada: http://www.polines. ac.id/ragam/index_files/jurnalragam/ppr $8 \% 20$ apr13.pdf.

Kamiludin A. 2009. Analisis Pendapatan Usaha Peternakan Sapi Perah di Kawasan Peternakan Sapi Perah Cibungbulang Kabupaten Bogor [skripsi]. Bogor (ID): Institut Pertanian Bogor. 51 hal.

Ridwan. 2011. Tentang Perusahaan: Koperasi Produksi Susu dan Usaha Peternakan (KPS) Bogor. [internet]. [diunduh 2014 Feb 21]. Terdapat pada: http://elib. unikom.ac.id/files/disk1/557/jbptunikompp-gdlridwannim1-27811-6-bab3-rid-n.pdf.

Santosa S. 2004. Dinamika Kelompok: edisi revisi cetakan ke-I. Jakarta (ID); Bumi Aksara.

Saragih B. 2000. Agribisnis Berbasis Peternakan: cetakan ke-II. Bogor (ID); PT Loji Grafika Griya Sarana.

Silalahi U. 2009. Metode Penelitian Sosial: cetakan ke-III. Bandung (ID); PT Refika Aditama.

Suryani L. 2011. Bab 2: Landasan Teori. [internet]. [diunduh 2014 Jul 20]. Terdapat pada: http:// repository.usu.ac.id/bitstream/123456789/28343/3/ Chapter\%20II.pdf.

[UU] Undang-Undang Nomor 10. 1992. Tentang Perkembangan Kependudukan dan Pembangunan Keluarga Sejahtera. [internet]. [diunduh 2014 Apr 3]. Terdapat pada: http://dinsosnaker-pemkomedan. info/file download/22_13-09-15-9-41-36_86975 $\operatorname{xxx}(6) \cdot \overline{p d f}$

[UU] Undang-Undang Republik Indonesia No 11. 2009. Tentang Kesejahteraan Sosial. [internet]. [diunduh 2014 Mar 17]. Terdapat pada: http://www.depkes. go.id/downloads/UU No. 11 Th 2009 ttg Kesejahteraan_Sosial.pdff. 